ISSN 2080-5993

\title{
Paweł Żukowski
}

Uczelnia Łazarskiego

\section{RYNEK WALUTOWY JAKO PRZYKLAD RYNKU WIRTUALNEGO}

\begin{abstract}
Streszczenie: W artykule opisane zostały przyczyny wirtualnej natury rynku walutowego określanego potocznie jako Forex. Jako system umożliwiający kupowanie i sprzedawanie walut charakteryzowany jest przez niematerialność towaru, dematerializację procesów transakcyjnych i wysoki poziom technologiczny. Czynniki te wpływają na kształt Foreksu, ale przede wszystkim przyczyniają się do systematycznego wzrostu jego obrotów. W pierwszej części artykułu opisana została niematerialność towaru rynkowego, jaki stanowią waluty. Następnie przedstawiono główne środki łączności używane do zawierania transakcji walutowych i narzędzia rynkowe, po czym nastąpił przegląd wirtualnej oferty polskiego internetowego Foreksu. Końcowym wnioskiem jest stwierdzenie, że rynek walutowy jest przykładem rynku wirtualnego ze względu na dominację niematerialnej formy współczesnych walut, które są towarem Foreksu, dematerializację zawierania transakcji walutowych i wysoki poziom techniczny narzędzi używanych przez uczestników Foreksu.
\end{abstract}

Słowa kluczowe: Forex, rynek walutowy, rynek wirtualny.

DOI: 10.15611/nof.2014.1.09

\section{Wstęp}

Rynek walutowy pojmowany jako system, który umożliwia kupowanie i sprzedawanie walut, dość powszechnie określany jest jako wirtualny. Warto zapytać, dlaczego tak się dzieje. Analiza przyczyn wirtualnego charakteru rynku walutowego, określanego potocznie jako Forex, jest głównym celem artykułu, a jego uzupełnieniem będzie zbadanie wpływu tych przyczyn na funkcjonowanie Foreksu.

W części pierwszej przedstawiona zostanie wirtualna natura towaru rynkowego, czyli walut. Część druga poświęcona zostanie analizie środków łączności stosowanych na rynku. Po niej nastąpi przegląd narzędzi, które umożliwiają dostęp do rynku, pozyskiwanie informacji i ich analizę. W czwartej części dokonany zostanie krótki przegląd oferty produktowej polskiego Foreksu. Część piąta zawiera omówienie podstawowych atrybutów wirtualności rynku walutowego i ich głównej konsekwencji. 
Sformułowane w artykule wnioski zostały oparte na obserwacjach własnych, dostępnej literaturze przedmiotu, analizie informacji rynkowej, a szczególnie: analizie metod zawierania transakcji walutowych, analizie przemian wyposażenia sprzętowego, analizie wpływu wprowadzania nowinek technologicznych na procesy rynkowe i na przeglądzie dostępnych ofert produktowych.

\section{Od waluty kruszcowej do pieniądza elektronicznego}

Przed wiekami, gdy ludzie chcieli dokonać wymiany monet pochodzących z różnych obszarów, spotykali się w większych miastach handlowych [Galbraith 1982, s. 32]. Monety te były najczęściej wykonane ze srebra, miedzi lub złota [Galbraith 1982, s. 28]. Ostatni z tych metali zdominował na wiele dziesięcioleci światowy system walutowy, ale po formalnym upadku systemu z Bretton Woods złoto przestało mieć monetarne znaczenie. Obok monet od wieków funkcjonują także banknoty. Te dwie formy pieniądza gotówkowego stanowią dzisiaj tylko jedno ze źródeł płynności. Obok nich jej źródłem są dzisiaj wkłady bankowe. Gdy były zapisywane piórem, dawały jeszcze pozory fizyczności. Dzisiaj coraz częściej spotykamy dominację pieniądza elektronicznego, a jeszcze na przełomie wieków jego rozwój określany był jako stadium wstępne [Kaźmierczak 2000, s. 29]. Pieniądz elektroniczny oznacza wyrażoną $\mathrm{w}$ jednostkach pieniężnych wartość stanowiącą elektroniczny odpowiednik znaków pieniężnych przechowywaną elektronicznie, wydawaną do dyspozycji na podstawie umowy w zamian za środki pieniężne o nominalnej wartości nie mniejszej niż ta wartość i przyjmowaną jako środek płatniczy (zob. [Obwieszczenie...]). Taki elektroniczny impuls traktowany jako waluta przenosi jego użytkowników w wirtualną rzeczywistość. Skoro waluty stają się w tym sensie wirtualne, to obrót nimi też jest już wirtualny. W czasach, kiedy waluty miały formę fizyczną, transakcje walutowe też musiały przybrać taką formę. Współczesne waluty przyjmują coraz częściej formę elektroniczną, a więc formę wirtualną. Skoro towar jest wirtualny, to rynek, na którym jest on przedmiotem obrotu, też musi być wirtualny. Spotkania ludzi pragnących wymienić waluty, które przed wiekami odbywały się w miastach handlowych, obecnie coraz częściej przyjmują formę transakcji wymiany walut niematerialnych w rzeczywistości wirtualnej.

\section{Od placu targowego do globalnej wioski walutowej}

W dawnych wiekach, jak wspomniano wcześniej, wymiana walut odbywała się w większych miastach handlowych [Galbraith 1982, s. 32]. Współcześnie przeprowadzana wymiana walut jest bardzo daleka od tej sprzed wieków. Pod koniec XX wieku rynek walutowy określano jako sieć połączonych telefonów i komputerów [Wurman, Siegel, Morris 1990, s. 112] Bankowe dealing roomy walutowe miały swój początek w okresie międzywojennym XX wieku, a pierwsze powojenne ban- 
kowe departamenty walutowe powstawały w późnych latach 40. i wczesnych 50 . XX wieku [Tygier 1983, s. 16]. Środkiem komunikacji był dla nich głównie telegraf, który był wtedy najszybszy [Tygier 1983, s. 15]. Pojawienie się dalekopisów i teleksów dało nowy impuls rozwojowy bankowym dealing roomom, a uzgadniane za ich pośrednictwem transakcje przestawały mieć fizyczną formę. Swoistym świadectwem podążania Foreksu za osiągnięciami techniki jest chociażby wejście do żargonu rynkowego określenia cable na nazwanie pary walutowej funt sterling-dolar amerykański (GBP/USD), co bezpośrednio nawiązywało do położonego w XIX wieku pod dnem Atlantyku kabla, który służył do telegraficznego przekazywania kursów walut między Londynem i Nowym Jorkiem [http://en.wikipedia.org/wiki/ Cable_\%28foreign_exchange\%29, 2012/11/17].

W dekadę lat 70. XX wieku rynek walutowy wszedł wyposażony w telefon i teleks. W 1973 r. ${ }^{1}$ uruchomiony został elektroniczny serwis Reuter Monitor Money Rates Service, a w 1981 r. firma Reuters wprowadziła Reuters Monitor Dealing Service (RMDS), który łączył dealerów walutowych ogólnoświatową siecią [http:// thomsonreuters.eom/about/company_history/\#1990_1980].

Lata 80. XX wieku zdominowane były przez telefon, brokerów głosowych i RMDS. W 1992 r. firma Reuters wprowadziła system Dealing 2000, który stał się pierwszym międzynarodowym brokerem kojarzącym komputerowo transakcje walutowe. Rok później wprowadzono stworzony przez grupę najważniejszych banków system EBS (Electronic Broking Services). W 1996 r. firma Reuters wprowadziła kolejną wersję maszyny [http://thomsonreuters.eom/about/company_history/\#1990_1980], jak dealerzy walutowi zaczęli nazywać elektronicznego brokera międzybankowego. Systemy te zaczęły przejmować rolę brokerów głosowych, z których wcześniej banki korzystały. Na rynku amerykańskim jeszcze w 1992 r. wszystkie transakcje zawierane za pośrednictwem brokerów były wykonywane przez brokerów głosowych, ale już w roku 1995 udział transakcji zawieranych przez brokerów elektronicznych osiągnął $6 \%$ obrotów rynkowych. Na rynku londyńskim w latach 1992-1995 pojawiło się 3 brokerów elektronicznych, którzy osiągnęli w 1995 roku 5\% obrotów rynku. Na rynku tokijskim, gdzie pierwsi elektroniczni brokerzy pojawili się we wrześniu 1992 r., po 3 latach działania obejmowali oni $32 \%$ transakcji zawieranych za pośrednictwem brokera i 4\% obrotów rynku [Central bank... 1996, s. 20].

Pod koniec XX wieku media elektroniczne wkroczyły również na rynek klientowski. Początkowo był to proces prostego zastępowania telefonu jako formy komunikacji klientów z bankami. Wprowadzona w 1996 r. platforma FX Connect, a przede wszystkim wprowadzona w roku 1999 platforma Currenex [www.currenex. com] dały rynkowi mocny impuls rozwojowy. Na przełomie wieków pojawiły się również walutowe platformy transakcyjne pojedynczych banków, a potem internetowe platformy przedsiębiorstw niebankowych.

\footnotetext{
${ }^{1}$ W tym samym roku oficjalnej likwidacji uległ system walutowy z Bretton Woods.
} 
Dzisiaj Internet jest tym, czym wcześniej dla bankowych dealerów walutowych był monitor Reutersa, a jeszcze dawniej teleks i telefon. Wszystkie te osiągnięcia techniki pozwalały zawierać transakcje na odległość. Dzięki temu na rynku walutowym, jeszcze przed upowszechnieniem się Internetu, urzeczywistniło się bardzo szybko wprowadzone przez M. McLuhana określenie świata jako globalnej wioski. Dealerzy walutowi połączeni systemem transakcyjnym firmy Reuters i brokerami głosowymi zawierali transakcje walutowe w globalnej wiosce. Upowszechnienie się Internetu sprawiło, że globalny rynek walutowy wyszedł poza bankowe dealing roomy. W konsekwencji Forex stał się globalną wioską walutową składającą się z internetowych miast - stron walutowych.

\section{Od nasłuchu i kursów gazetowych do algotradingu}

W starożytnym i średniowiecznym świecie do wymiany walut wystarczały ludziom prawdopodobnie: waga, zmysły i siły fizyczne, a także podstawowe umiejętności liczenia i rozpoznawania monet. Dzisiaj porównywanie wartości walut pochodzących z różnych obszarów odbywa się na monitorze komputera lub na wyświetlaczu telefonu komórkowego, co zmienia zdecydowanie wymagania uczestników Foreksu. W konsekwencji zmieniło się pojmowanie tego, co nazywane jest łatwością dostępu do rynku. Dzisiaj, zamiast podróży do najbliższego miasta handlowego, każdy może poruszać się w wirtualnej rzeczywistości i w ułamku sekundy trafić na internetową stronę walutową, czego przykładem może być kierowana do polskich klientów oferta TMS Brokers [www.tms.pl/o-nas/historia-firmy]. Opierając się na interfejsie strony internetowej, TMS Brokers zapewnia klientom dostęp do platformy transakcyjnej z każdego podłączonego do Internetu komputera (TMS WebDirect) bądź za pomocą telefonu komórkowego $\mathrm{z}$ dostępem do Internetu (TMS MobiDirect) [www. tms.pl/tms-direct/webdirect, www.tms.pl/tms-direct/mobidirect].

Za sprawą postępu technologicznego zmienia również swój wymiar to, co nazywane jest aktualną wiedzą o rynku. Przed wieloma laty wystarczyło sprawdzić kurs walutowy w gazecie lub zadzwonić do dealera walutowego, który wiedzę o kursach pozyskiwał od brokera głosowego lub od innego dealera walutowego. To samo jest i dzisiaj możliwe. Tyle tylko, że tak sprawdzony kurs jest już najczęściej całkowicie nieaktualny. Choć nadal prawdziwe jest dealerskie powiedzenie, że kurs jest aktualny aż do chwili pojawienia się nowego kursu [Taylor 2000, s. 33], to czas do najbliższej zmiany skrócił się obecnie do ułamków sekundy, czego ludzkie zmysły nie są w stanie rejestrować. Prawidłowa rejestracja zmian o tak wysokiej częstotliwości jest niemożliwa bez zastosowania narzędzi informatycznych. Współczesny Forex znalazł na to rozwiązanie, czego przykładem jest chociażby usługa Alert proponowana klientom przez BRE Bank. Usługa Alert polega na przekazaniu pocztą elektroniczną lub SMS-em informacji o osiągnięciu lub przekroczeniu wybranego kursu walutowego [Regulamin świadczenia... 2012, s. 2]. Bez narzędzi informatycznych nie jest również możliwe archiwizowanie kursów i ich zmian. W połącze- 
niu z internetowymi źródłami danych pozwalają one na automatyczne rejestrowanie i archiwizowanie każdego nowo pojawiającego się w globalnej wiosce walutowej kursu walutowego. Dzięki temu staje się możliwe sprawne budowanie archiwów kursowych i wykresów służących do analizy technicznej trendów rynkowych. Przykładem takiej usługi jest oferta platformy Currenex, która umożliwia dostęp do danych historycznych i bieżących, tworzenie wykresów opartych na kursach transakcyjnych oraz korzystanie z narzędzi analizy technicznej opartych na tych wykresach. Jej użytkownik w ułamku sekundy może ponadto otrzymać m.in. raporty i szczegóły zawartych transakcji w wymaganych przez siebie przekrojach, ich szczegóły płatnicze, integrację z systemami zarządzania finansowego, bazy cen dla transakcji, odnajdywanie najlepszych kursów transakcyjnych i wiele innych przydatnych narzędzi [www.currenex.com/pre_post_news_analysis.html].

Sprawne poruszanie się na rynku walutowym nie jest obecnie możliwe bez szybkich obliczeń. Nawet tak proste obliczenia jak kalkulacja kursów krzyżowych wykonywane w pamięci lub na kartce pod presją czasu mogą okazać się zawodne ze względu na konieczność wykonywania obliczeń na wielocyfrowych liczbach. Upowszechnienie się niewielkich przenośnych urządzeń zwanych elektronicznymi kalkulatorami, a potem kalkulatorów programowalnych bardzo usprawniło i przyspieszyło proces kalkulacji nie tylko kursów krzyżowych, ale i wszystkich innych obliczeń. Wprowadzone później arkusze kalkulacyjne i elektroniczne bazy danych jeszcze mocniej usprawniły takie kalkulacje. Jeszcze w latach 60. ubiegłego wieku proste dzielenie na mechanicznym kalkulatorze zajmowało około 30 sekund, a złożone kalkulacje mogły trwać kilkanaście minut [Tygier 1983, s. 17]. Dzisiaj liczące telefony i komputery dają wyniki złożonych obliczeń w ułamku sekundy.

Rozwój technologii i technik wirtualnych zmienia również samo zawieranie transakcji, czego dobrym przykładem jest handel algorytmiczny (algo, algorithmic trading). Polega on na zawieraniu transakcji walutowych, opierając się na decyzjach podejmowanych automatycznie na podstawie programu komputerowego. W praktycznym wymiarze oznacza to tyle, że podejmowanie decyzji o zawarciu transakcji dokonywane jest przez komputer bez udziału człowieka (zob. [King, Osler, Rime 2011, s. 39]).

W konsekwencji w dzisiejszej rzeczywistości wirtualnej jedno kliknięcie myszką umożliwia nie tylko sprawdzenie bieżących kursów, wyliczenie pozycji walutowej, nie tylko zbudowanie wykresu, przeprowadzenie analizy technicznej czy wreszcie porównanie prognoz rynkowych, ale pozwala wręcz na zawarcie transakcji walutowej.

\section{Przegląd polskiego i-Foreksu}

Z perspektywy polskiego użytkownika jeszcze 30 lat temu rynek walutowy praktycznie nie istniał. Używane wtedy określenie „cinkciarz” oznaczało człowieka, który w okolicach sklepów Pewex handlował nielegalnie walutą. Dzisiaj cinkciarz jest nazwą jednego z kantorów internetowych (Cinkciarz.pl), który, jak przeczytać można $\mathrm{w}$ jego serwisie internetowym, oferuje działające przez całą dobę systemy trans- 
akcyjne pozwalające na wymianę 25 walut, a także wiele narzędzi wspomagających przeprowadzanie transakcji walutowych [https://cinkciarz.pl/o-nas/opis-dzialalnosci]. Współczesna światowa wioska walutowa oferuje polskiemu uczestnikowi wiele różnych usług, od prostego kupna i sprzedaży różnych walut i internetowego rozliczenia począwszy, na wymianie poglądów i prognoz kończąc. Banki i inni uczestnicy internetowego Foreksu systematycznie wprowadzają nowe pary walutowe, czego przykładem może być choćby informacja, jaka w styczniu $2013 \mathrm{r}$. widniała na stronie internetowej banku BPH. Bank informował o wprowadzeniu na swojej platformie walutowej DealingNet możliwości zawierania transakcji natychmiastowej dla chińskiego juana [www.bph.pl/pl/firmy/transakcie-skarbowe-i-powiernicze/dealingnet]. Rosnące możliwości zawierania transakcji przez Internet znajdują odbicie w rosnącym udziale transakcji internetowych w obrotach walutowych. W kwietniu $2010 \mathrm{r}$. udział transakcji walutowych zawieranych na platformach walutowych oferowanych przez pojedyncze banki wyniósł $13 \%$ obrotu krajowego rynku transakcji natychmiastowych, a 3 lata wcześniej stanowił jedynie 2\% [Rozwój systemu... 2012, s. 239]. Można się spodziewać, że ten dynamiczny wzrost obrotów walutowych na platformach internetowych będzie się pogłębiał. Taki bowiem trend jest wyraźnie widoczny na światowym rynku walutowym, czego obraz przedstawiony jest na rys. 1. W 2013 r. ponad trzy piąte światowych obrotów walutowych przeprowadzone zostało za pośrednictwem kanałów elektronicznych. Udział transakcji zawartych na platformach bankowych (electronic direct) w kwietniu $2013 \mathrm{r}$. wyniósł ponad $37 \%$. Natomiast transakcje zawarte poprzez elektroniczne systemy brokerskie automatycznie kojarzące oferty kupna i sprzedaży walut (electronic indirect) stanowiły ponad $26 \%$ obrotów. Zdecydowanie mniejszy udział miały pozostałe formy zawierania transakcji. Metoda głosowa bezpośrednia (voice direct), w której transakcje zawierane są telefonicznie bezpośrednio między kontrahentami, stanowiła jedną czwartą obrotów. Natomiast metoda głosowa pośrednia (voice indirect), w której transakcje zawierane są telefonicznie przez brokera, stanowiła mniej niż jedną dziesiątą obrotów w kwietniu roku 2013.

Choć w wielu przypadkach Forex internetowy nadal jedynie zastępuje transakcje telefoniczne, to regułą stało się, że już przynosi klientom także inne korzyści. Wśród takich korzyści bank BPH wymienił m.in.: arkusz otwartych sald, który pomaga $\mathrm{w}$ zarządzaniu płynnością $\mathrm{w}$ różnych walutach, szczegółowe raporty, które pomagają w księgowaniu zwartych transakcji [Broszura informacyjna..., s. 5]. Jako dodatkowe zalety wymieniany jest również dostęp do informacji agencyjnych i analiz ekonomicznych banku [Rozwój... 2012a s. 239; Rozwój... 2012b, s. 331]. Jak można było przeczytać w styczniu 2013 r. na stronie XTB, klient firmy może codziennie skorzystać z raportów rynkowych i analizy technicznej rynku Forex, może otrzymać do 2000 informacji dziennie i wreszcie mieć dostęp do rynku w czasie rzeczywistym [www.xtb.pl/strefa-analityczna/Trading-Central, 2013/01/14]. Z kolei BRE Bank w październiku 2012 r. rozszerzył swoją platformę iBRE FX m.in. o takie funkcjonalności, jak: alerty, oferty, czyli zawarcie transakcji na podstawie złożonej 


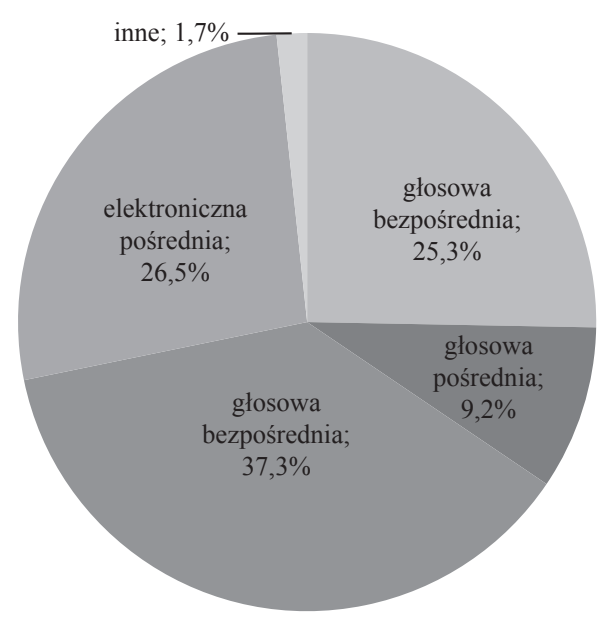

Rys. 1. Struktura metod zawierania natychmiastowych transakcji walutowych na świecie w kwietniu $2013 \mathrm{r}$.

Źródło: opracowanie własne na podstawie: [Triennial... 2014, s. 73].

wcześniej oferty kupna lub sprzedaży waluty po wybranym kursie, web servisy, czyli możliwość integracji systemu informatycznego klienta z platformą iBRE FX [www.brebank.p1/bankowosc_elektroniczna/iBRE/iBRE_FX/].

Polski uczestnik Foreksu może skorzystać także z social trading, czyli połączenia portalu internetowego z elektronicznym zawieraniem transakcji walutowych. Transakcja walutowa zawierana jest na platformie walutowej, a decyzję o jej zawarciu podejmuje się na podstawie transakcji zawartych przez innego uczestnika lub innych uczestników tego portalu. Przykładem takiego naśladowczego zawierania transakcji walutowych jest choćby xSocial oferowany przez XTB [patrz: www.xtb. $\mathrm{pl} /$ oferta/xSocial].

Wśród firm oferujących w Polsce internetowy Forex są nie tylko te rodzime, ale także zagraniczne, np. firma Admiral Markets, która aktywnie oferuje usługi foreksowe w Polsce i ma licencję wydaną przez Estońską Komisję Nadzoru Finansowego (EFSA) [http://www.admiralmarkets.pl/company/license]

\section{Wirtualny wymiar rynku walutowego}

Przymiotnik ,wirtualny” jest dzisiaj bardzo często używany, i to w bardzo wielu znaczeniach, choć jego historia jest stosunkowo krótka. Jeszcze w wydanym w $1981 \mathrm{r}$. Słowniku języka polskiego termin taki nie występował (zob. [Słownik języka polskiego... 1981]). Mogłoby to wskazywać, że przymiotnik „wirtualny” funkcjonuje w języku polskim krócej niż 30 lat. Pod określeniem „wirtualny” kryje się coś teoretycznie możliwego, coś, co może zaistnieć [Słownik wyrazów obcych... 1993, 
s. 906]. Rzeczywistość wirtualna jest sztuczną rzeczywistością, przestrzenią cybernetyczną albo komputerową symulacją, której celem jest stworzenie wrażenia przebywania w sztucznie wykreowanym świecie [Nowa encyklopedia... 1997, s. 802]. Rynek walutowy, jak zresztą wiele innych segmentów rynku finansowego, zawiera wiele elementów sztucznie wykreowanych, mających wirtualny charakter.

Pierwszym z tych elementów jest niematerialność towaru rynkowego, jakim są waluty. Wirtualność Foreksu budowana jest również przez niefizyczny i niewymagający przemieszczania się sposób zawierania transakcji walutowych, w którym kupujący nie spotyka się ze sprzedającym w fizycznym wymiarze. Przejawia się on zarówno we wzroście transakcji zawieranych za pośrednictwem elektronicznych kanałów, jak i we wzroście ich bezwzględnej wartości. W roku 2010 ponad połowa obrotów rynku walutowego zawierana była za pośrednictwem elektronicznych brokerów, multibankowych systemów tradingowych lub platform indywidualnych banków [King, Rime 2010, s. 32-33], co przedstawiono na rys. 1. Wśród tych elektronicznych kanałów zawierania transakcji walutowych znajdują się m.in. automatyczne systemy kojarzące oferty, takie jak np. EBC czy Reuters Matching, platformy pojedynczych banków, za pomocą których ich klienci zawierają transakcje walutowe bez fizycznego udziału dealerów walutowych ${ }^{2}$.

Dominacja elektronicznych kanałów transakcyjnych przejawia się nie tylko w ich wysokim udziale wśród metod zawierania transakcji walutowych, ale również w wysokiej, a w niektórych przypadkach bardzo wysokiej dynamice wzrostu wielkości obrotów walutowych dokonywanych za ich pośrednictwem. Przykładem tej wysokiej dynamiki jest przyrost obrotów walutowych w ostatnich latach, czego obraz widoczny jest na rys. 2. W roku 2013 wielkość obrotów transakcji natychmiastowych była o prawie połowę większa niż w roku 2010. Dla terminowych transakcji walutowych obroty w 2013 r. były wyższe o ponad 75\% niż 3 lata wcześniej. W przypadku swapów walutowych wzrost ten przekroczył 90\%. Natomiast obrót opcjami walutowymi w roku 2013 był 4 razy wyższy niż w roku 2010, choć był zdecydowanie niższy dla pozostałych typów transakcji walutowych.

Obok wirtualności towaru rynku walutowego, czyli walut, i dematerializacji procesów transakcyjnych, przyczyną wysokiego stopnia wirtualności Foreksu jest wysoki stopień zaawansowania technologicznego, czego przejawem jest przede wszystkim konieczność stosowania zaawansowanych narzędzi i technik komputerowych podczas wykonywania nawet najprostszych czynności. Bez komputera, laptopa czy telefonu nie można dzisiaj praktycznie ani zawrzeć transakcji, ani wyliczyć kursów, ani policzyć pozycji walutowej, ani wreszcie dokonać analizy trendów rynkowych. Wysoki stopień poziomu technologicznego sprawia, że systematycznie zmniejsza się konieczność bezpośredniego udziału człowieka w zawieraniu transakcji i innych procesach rynkowych. Przez wirtualizację człowiek systematycznie

${ }^{2}$ BIS Triennial Central Bank Survey Report on global foreign exchange market activity in 2010 Monetary and Economic Department, December 2010, s. 35. 


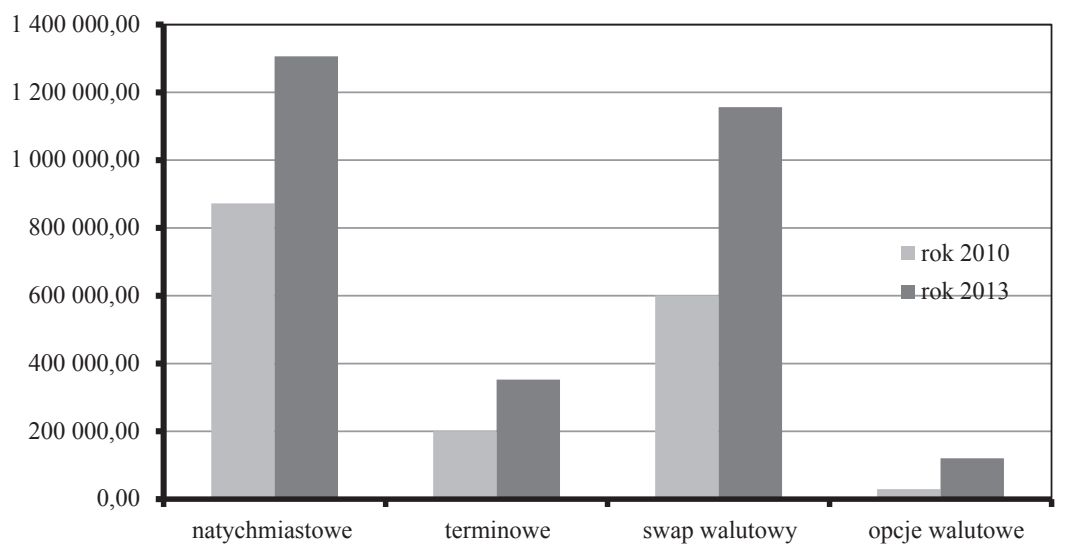

Rys. 2. Dzienne obroty światowego rynku walutowego w elektronicznych kanałach w podziale na podstawowe typy transakcji walutowych w kwietniu 2010 i w kwietniu 2013 r. (w mld USD)

Źródło: opracowanie własne na podstawie: BIS Triennial Central Bank Survey Report on global foreign exchange market activity in 2010 Monetary and Economic Department, December 2010, s. 88 oraz BIS Triennial Central Bank Survey Global foreign exchange market turnover in 2013 Monetary and Economic Department, February 2014, s. T_01_01.

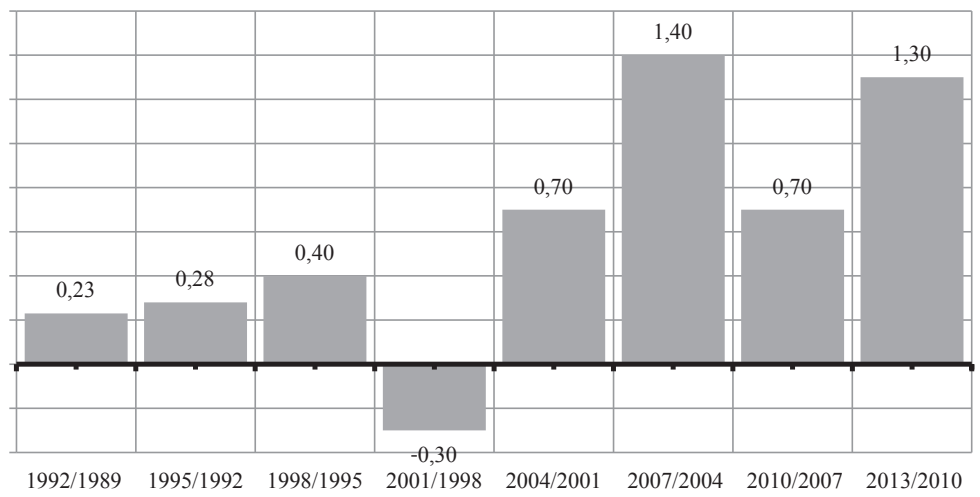

Rys. 3. Zmiana dziennych obrotów światowego rynku walutowego w latach 1989-2013 (w bln USD)

Źródło: obliczenia własne na podstawie: BIS Triennial Central Bank Survey Report on global foreign exchange market activity za odpowiednie lata.

eliminowany jest $\mathrm{z}$ bezpośredniego udziału w przygotowywaniu, zawieraniu, rozliczaniu i analizowaniu transakcji walutowych. Ten, kto chce dzisiaj zawrzeć transakcję walutową, nie musi jechać do innego miasta. Nie musi również iść do banku. Nie musi nawet do niego dzwonić. Wystarczy, że uruchomi swoje urządzenie komputerowe lub mobilne i za jego pośrednictwem zawrze transakcję walutową. Nie musi też sprawdzać i ważyć monet, bo pieniądz nie ma dzisiaj fizycznej formy. Nie musi nawet liczyć, bo komputer policzy za niego. Nie musi dowiadywać się 
o kurs, bo dostanie SMS-a lub e-mail, a komputer to sam zarejestruje. Nie musi dokonywać samodzielnej analizy trendów rynkowych, bo komputer zrobi to za niego. Nie musi wreszcie podejmować samodzielnej decyzji o zawarciu transakcji i sam jej zawierać, bo i to komputer może zrobić za niego. Nawet jeśli po chwili zastanowienia człowiek dojdzie do wniosku, że przecież to wszystko zaprogramowane zostało przez człowieka, to i tak uznaje, że rynek walutowy jest wirtualny. To sprawia m.in., że Forex stanowi przykład rynku wirtualnego, czyli rynku, który funkcjonuje przede wszystkim w środowisku wirtualnym.

Wirtualność towaru rynkowego, czyli walut, dematerializacja procesów transakcyjnych oraz wysoki poziom technologiczny są przyczyną różnorodnych przemian Foreksu, wśród których najważniejszą jest dynamiczny wzrost obrotów. Jak zaprezentowano na rys. 3, z wyjątkiem przełomu wieków, co można wiązać z wprowadzeniem wspólnej europejskiej waluty, obroty walutowe systematycznie rosną. Analiza pokazuje ponadto bardzo wyraźnie, że w obecnym stuleciu przyrosty te były kilkakrotnie razy wyższe niż w latach 90 . ubiegłego stulecia. A skoro w obecnym stuleciu poziom technologiczny Foreksu jest zdecydowanie wyższy niż w końcu ubiegłego wieku, to wręcz naturalnym wnioskiem staje się stwierdzenie, że wzrost obrotów walutowych na świecie jest skutkiem jego rosnącego poziomu technologicznego i wejścia w świat Internetu.

\section{Wnioski}

Zmiany technologiczne przenoszą Forex w rzeczywistość wirtualną, choć zwykle za główną siłę sprawczą przemian rynku walutowego uznawane są przemiany systemów walutowych i przepisów prawa. Wirtualność towaru, dematerializacja procesów rynkowych i wysoki poziom technologiczny są głównymi przyczynami wirtualnej natury współczesnego rynku walutowego. W konsekwencji może dojść do paradoksalnej sytuacji, że do uczestniczenia w Foreksie nie będzie potrzebne nic więcej oprócz odpowiednich wirtualnych narzędzi. Nawet jeśli nigdy do tego nie dojdzie, to rosnąca świadomość, że o wszystkim decydują komputery, pogłębia przekonanie o wirtualnej naturze rynku walutowego.

Niematerialność walut, dematerializacja procesów transakcyjnych i wysoki poziom technologiczny zdecydowały o wejściu Foreksu w fazę wirtualną. Czynniki te spowodowały wiele różnorodnych skutków, wśród których wzrost obrotów walutowych jawi się jako najważniejszy. Dostrzegalne jest tutaj sprzężenie zwrotne, ponieważ czynniki te są przyczyną wzrostu obrotów, a jednocześnie wzrost obrotów wymusza ich rozwój. Wzrost poziomu technologicznego pozwala na coraz częstsze zawieranie transakcji, a zwiększona częstotliwość zawierania transakcji wymusza wzrost technicznego poziomu używanych narzędzi transakcyjnych. Takie sprzężenie zwrotne, choć nie jest unikatowe dla rynku walutowego, jest na nim bardzo powszechne i dynamiczne. Choć podobnych związków przyczynowo-skutkowych można odnaleźć więcej, to wpływ opisanych czynników na kształt współczesnego 
Foreksu jest dobrą ilustracją wirtualnej natury współczesnego rynku walutowego. $\mathrm{W}$ jego funkcjonowaniu dostrzec można również swoisty paradoks, który polega na tym, że opisane czynniki wirtualne prowadzą do wzrostu obrotów walutowych, a te z kolei wymuszają dalszy rozwój poziomu zdematerializowania towaru i procesów rynkowych, co zwiększa poziom wirtualizacji współczesnego rynku walutowego.

\section{Literatura}

Broszura informacyjna Banku BPH, DealingNet - rynek walutowy on-line.

Central bank survey of foreign Exchange and derivatives market activity za odpowiednie lata, BIS, Bazvlea.

Galbraith J.K., Pieniadz - pochodzenie i losy, Państwowe Wydawnictwo Ekonomiczne, Warszawa 1982.

Kaźmierczak A., Polityka pieniężna w gospodarce rynkowej, Wydawnictwo Naukowe PWN, Warszawa 2000.

King M.R, Osler C., Rime D., Foreign exchange market structure, players and evolution, Working Paper, Norges Bank, 2011/10.

King M.R., D. Rime D., The \$4 trillion question: what explains FX growth Since the 2007 survey?, "BIS Quarterly Review", December 2010.

Nowa encyklopedia powszechna PWN, tom 6 S-Z, Wydawnictwo Naukowe PWN, Warszawa 1997.

Obwieszczenie Marszałka Sejmu Rzeczypospolitej Polskiej z dnia 2 kwietnia 2014 r. w sprawie ogłoszenia jednolitego tekstu ustawy o usługach płatniczych (DzU 2014, poz. 873).

Regulamin świadczenia Klientom przez BRE Bank SA usługi informacyjnej Newsletter oraz usługi Alert, Warszawa, grudzień 2012.

Rozwój system finansowego w Polsce w 2010 r., NBP, Warszawa 2012a.

Rozwój systemu finansowego w Polsce w 2011 r., NBP, Warszawa 2012 b.

Stownik języka polskiego, tom III, Państwowe Wydawnictwo Naukowe, Warszawa 1981.

Stownik wyrazów obcych, wydanie XXVII, Wydawnictwo Naukowe PWN, Warszawa 1993.

Taylor F., Rynki i opcje walutowe - rozwój, struktura, transakcje, Dom Wydawniczy ABC, Kraków 2000.

Triennial Central Bank Survey Global foreign exchange market turnover in 2013 Monetary and Economic Department February 2014.

Tygier C., Basic Handbook of Foreign Exchange - A Guide to Foreign Exchange Dealing, Euromoney Publication Limited, London 1983.

Wurman R.S., Siegel A., Morris K.M., Guide to Understanding Money \& Markets, The Wall Street Journal, An Access Press Publication Ltd. and Siegel \& Gale Inc. New York 1990.

Wybrane strony internetowe dostawców internetowych usług walutowych.

\section{FX MARKET AS AN EXAMPLE OF THE E-MARKET}

Summary: The paper describes the e-nature of FX market (Forex). As a system that enables buying and selling currencies it has been characterized by the dematerialization of its commodity, decreasing of human participation and high technology level. Firstly the e-nature of currencies being FX market commodity has been presented. Than the main communication and other market tools have been described. The review of the Polish eForex has been fol- 
lowed by the mentioning of the main Forex features being dematerialization and the high technology level. As the final conclusion it has been stated that the foreign exchange market is an example of the on-line market due to the dominance of non-material forms of currencies being the Forex commodities, no need for the physical contact for FX deals and the dominance of the activity of the FX market participants in the online environment.

Keywords: Forex, FX market, e-market. 